\title{
WEBSITE PENGARSIPAN DOKUMEN DAN SURAT PADA JURUSAN SISTEM INFORMASI UNIVERSITAS MUSAMUS
}

\author{
Reza Zubaedah ${ }^{1}$, Nasra Pratama Putra ${ }^{2}$ \\ ${ }^{1,2}$ Jurusan Sistem Informasi, Fakultas Teknik, Universitas Musamus Merauke. \\ Email: ${ }^{1}$ rzubaedah@unmus.ac.id, ${ }^{2}$ nasrapratama@unmus.ac.id,
}

\begin{abstract}
ABSTRAK
Jurusan Sistem Informasi merupakan salah satu jurusan di Universitas Musamus. Bersadarkan Surat Kepeutusan Pendirian No 160/D/O/2006 Berdiri pada tanggal 16 Agustus 2006. Hingga saat ini jurusan Sistem Informasi memiliki banyak sekali dokumen dan arsip. Peraturan Menteri Negara Pendayagunaan Aparatur Negara dan Reformasi Birokrasi Republik Indonesia Nomor 6 Tahun 2011 mengharuskan Jurusan Sistem Informasi menghadirkan kegiatan pengarsipan secara elektronik. Permasalahan yang muncul hingga saat ini kegiatan pengarsipan di Jurusan Sistem Informasi memang dilakukan secara elektronik. Elektronik yang dimaksud adalah menggunakan Microsoft Excel. Sehingga belum dapat melakukan pencarian cepat. Rekapitulasi jumlah dokumen masih juga harus dihitung secara manual. Penanganan khusus terhadap dokumen (arsip) diberikan terutama saat menghadapi akreditasi jurusan. Arsip harus terpelihara dan mudah ditemukan bila diperlukan. Hasil penelitian menunjukkan website yang dibangun mampu mengelola arsip baik. Arsip tersimapan dalam web berbentuk dokumen SOP, surat keputusan, surat keluar, surat masuk. Website dingun dengan menggunakan framework Bootstrap. Framework front-end Bootstrap yang lengkap mampu menciptakan website yang lebih responsif dan mudah. Selain dari pada kebutuhan jurusan Sistem Informasi sendiri, website ini juga bisa menjadi framework dasar bagi Jurusan lain di Universitas Musamus.
\end{abstract}

Kata Kunci: Sistem, informasi, arsip, dokumen, surat, website 


\section{PENDAHULUAN}

Kegiatan pengarsipan dikenal sebagai kegiatan yang sangat penting dalam ketatalaksanaan suatu instansi tertentu. Sering dilakukan terutama pada intansi pemerintahan. Pemerintah menghimbau pada semua instansi untuk menyusun tata naskah dinas secara elektronik. Hal tersebut mengacu pada Peraturan MENPANRB Nomor 6 Tahun 2011 mengenai Pedoman Umum Tata Naskah Dinas Elektronik di Lingkungan Instansi Pemerintah [3]. Melalui pedoman tersebut, maka dokumen dan surat harus disimpan dengan baik secara elektronik. Kegiatan pengarsipan secara elektronik ini tentu wajib dilaksanakan oleh seluruh intansi pemerintah tidak terkecuali di Universitas Musamus.

Jurusan Sistem Informasi merupakan salah satu jurusan di Universitas Musamus yang berdiri pada tanggal 16 Agustus 2006 dengan SK Pendirian 160/D/0/2006. Secara kurikulum, jurusan Sistem Informasi mengajarkan mahasiswanya beberapa mata kuliah inti dalam bidang IT termasuk pemrograman web. Namun dengan beberapa matakuliah pemrograman yang dijarkan, hingga saat ini program pengolahan pengarsipan dokumen dan surat secara elektronik belum dimiliki oleh jurusan Sistem Informasi. Ini merupakan suatu masalah penting yang harus segera ditangani, mengingat pentingnya keberadaan dan fungsi arsip sebagai peningkatan jaminan mutu dan pelayanan.

Proses penyimpanan secara manual dapat memungkinkan data hilang. Selain hilang, data dapat rusak serta sulit dalam melakukan pencarian data. Padahal tanpa diketahui, data tersebut suatu waktu diperlukan. Penanganan khusus diberikan terutama pada kondisi menghadapi akreditasi jurusan. Seluruh dokumen baik dalam bentuk soft maupun hard harus terpelihara. Pencarian dokumen harus dapat dengan mudah ditemukan. Sehingga perlu dihadirkan suatu teknologi IT terbaru dalam manajemen dokumen. Desain teknologi tersebut untuk mengelola dokumen mutu secara elektronik. Bahkan dapat diterapkan dalam suatu database yang telah terintegrasi[4].

Berbagai produk sistem informasi pengelolaan arsip yang sudah beredar dipasaran rata-rata hanya menitikberatkan pada pengarsipan surat keluar dan surat masuk[5]. Sedangkan terdapat juga produk sistem informasi yang bertujuan sebagai pengendalian dokumen. Produk ini diawali dengan tahap permintaan nomor dokumen melalui sistem. Kemudian terbit dokumen baru. Dan distribusikan sebagai tahap akhir. Tujuannya sistem disini guna mengurangi resiko lamanya permintaan nomor dokumen. Permintaan nomor tanpa sistem diproses secara manual kepada unit pengendali dokumen[6]. Meskipun produk tersebut telah mampu melakukan pencariaan, 
MUSTEK ANIM HA Vol. 8 No. 1, April 2019

e-ISSN : 2354-7707 p-ISSN 2089-6697

pengunggahan, dan pengunduhan, namun Tujuannya untuk mengurangi biaya, penggunaan sistem tersebut masih meningkatkan kemampuan, bahkan menggunakan jaringan LAN (Local Access meningkatkan prestasi dari sistem informasi. Network).

Untuk menutupi kelemahan sistem pengarsipan pada penelitian sebelumnya, penulis akan membuat suatu website yang mampu mengelola arsip baik dalam bentuk dokumen SOP, surat keputusan, surat keluar, surat masuk hingga memo/disposisi dengan menggunakan framework Bootstrap. Penggunaan website dapat menyelesaikan masalah penggunaan jaringan local sehingga dapat diporoses kapanpun dan dimanapun. Selain itu, kelebihan menggunakan Bootstrap sebagai framework front-end yang lengkap. Bootstrap digunakan sebagai pengembangan website yang responsif dan mudah. Selain dari pada kebutuhan jurusan Sistem Informasi sendiri, website ini juga bisa menjadi framework dasar bagi jurusan lain di Universitas Musamus.

\section{TINJAUAN PUSTAKA}

\section{Sistem Informasi Pengarsipan}

Informasi sebagai bahan terpenting bagi pengelola dan manajemen[2]. Pada organisasi terdapat batasan dalam memberikan informasi. Batasan tersebut berasal dari data yang dapat diperoleh. Selain itu juga biaya untuk pengadaan, pengolahan dan penyimpanan dsb. Sistem informasi dapat diolah menggunakan komputer. Suatu sistem dapat dihimpun dari kombinasi orang, fasilitas, teknologi, media, prosedurprosedur dan pengendalian. Tujuannya guna menghasilkan jalur komunikasi yang penting dalam pengolahan tipe transaksi rutin tertentu. Kemudian dapat mengirim sinyal kepada manajemen mengenai kejadian intenal dan eksternal. Terakhir, dapat digunakan sebagai dasar pengambilan keputusan yang cerdik [1].

Berbagai kumpulan dokumen penting yang disimpan secara teratur berdasarkan sistem dapat dikenal dengan sebutan arsip. Beberapa kegunaan arsip, yaitu:

1. Untuk sumber ingatan atau memori. Arsip yang tersimpan pada bank data yang dapat dijadikan rujukan pencarian informasi bila dibutuhkan.

2. Untuk bahan pengambilan keputusan. Pihak manejemen tentunya mengolah dan menggunkan data atau informasi sebagai bahan pertimbangan pengambilan keputusan.

3. Untuk bukti atau legalitas. Arsip pada organisasi berfungsi sebagai pendukung legalitas atau bukti - bukti apabila dibutuhkan.

4. Untuk rujukan historis. Arsip mampu merekam informasi. Informasi ini bisa 
dari masa lalu. Selain itu juga dapat digunakan untuk masa akan datang.

Dari beberapan referensi ahli dan teori, penulis mencoba menyimpulkan pemahaman Sistem Informasi Pengarsipan. Sistem informasi pengarsipan dapat digambarkan sebagai kumpulan prosedur-prosedur. Prosedur dilakukan dengan cara pengolahan harian arsip secara logis dan sistematis. Pengolahan dilakukan dengan menggunakan abjad, numerik/nomor, huruf ataupun kombinasi huruf dan nomor sebagai identitas. Pengolahan dapat bersifat manajerial dan kegiatan strategi untuk dijadikan bahan referensi. Tujuan akhir pengarsipan tidak lain untuk menginformasikan informasi yang tepat pada organisasi.

\section{Framework Bootstrap}

Salah satu framework front-end yang lengkap daan banyak dipakai untuk pengembangan website dikenal dengan nama Bootstrap. Framework ini mencakup template desain berbasis HTML dan CSS untuk komponen antarmuka pengguna biasa seperti tipografi, form, button, tabel, navigasi, dropdown, alert, modal, tab, accordion, carousel dan banyak ekstensi JavaScript lainnya.

Bootstrap dahulu memiliki istilah Twitter Blueprint. Dikembangkan oleh Mark Otto dan Jacob Thornton di Twitter.
Tujuannya sebagai framework yang dapat mendorong konsistensi di lingkungan aplikasi internal mereka. Bootstrap hadir untuk mengurangi ketidakkonsistenan dan beban pemeliharaan yang tinggi.

Membuat framework CSS yang fleksibel atau responsive, mengikuti standar terbaru dan benar-benar teruji membutuhkan waktu kerja yang panjang dan bisa menjadi proyek besar. Dengan munculnya perangkat mobile, membuat situs web yang responsif dan mengikuti teknologi terbaru akan sangat menyita waktu untuk pengembangan user interfacenya.

Kebutuhan untuk membuat website yang responsive adalah sebuah keharusan pada masa sekarang ini. Google pun telah mewanti-wanti pengembang web untuk selalu memperhatikan bagaimana tampilan website mereka di perangkat mobile. Tentunya tanpa mengurangi fitur dan konten yang ditampilkan pada tampilan desktop. Framework Bootstrap menjawab itu semua.

Berikut adalah beberapa keuntungan lainnya, mengapa Anda harus memilih Bootstrap:

1. Hemat banyak waktu

Anda dapat menghemat banyak waktu dan usaha menggunakan template dan komponen Bootstrap yang telah ditentukan dan berkonsentrasi pada pekerjaan pengembangan lainnya.

2. Fitur responsive 
Dengan menggunakan Bootstrap, desain menjadi responsif. Fitur ini membuat halaman web Anda tampil lebih baik pada perangkat. Tidak hanya itu, boostrap juga merespon resolusi layar yang berbeda dengan baik tanpa terdapat perubahan markup.

3. Desain yang konsisten

Semua komponen Bootstrap merupakan template dan gaya desain yang sama, sehingga desain dan tata letak halaman web Anda konsisten selama Anda melakukan pengembangan website.

4. Mudah digunakan

Dikenal dengan kemudahannya. Siapa saja yang memiliki pengetahuan dasar tentang HTML dan CSS dapat memulai pengembangan dengan Bootstrap.

5. Kompatibel dengan semua browser

Bootstrap dibuat dengan browser modern dan kompatibel dengan semua browser. Contoh browser populer layaknya Mozilla Firefox, Google Chrome, Safari, Internet Explorer, dan Opera.

6. Open Source

Gratis untuk diunduh dan digunakan.

7. Dokumentasi yang lengkap

Bootstrap tidak hanya menawarkan styling untuk hampir setiap elemen yang dibutuhkan aplikasi situs web atau web biasa, namun juga menyediakan dokumentasi yang sangat lengkap dengan contoh dan demo yang membuatnya lebih mudah bagi pengguna baru sekalipun.

Selain itu, Bootstrap membutuhkan jQuery untuk berbagai komponennya. jQuery adalah perpustakaan JavaScript yang sangat populer dan banyak digunakan, yang menyederhanakan dan menambahkan kompatibilitas ke semua browser.

\section{Aliran Sistem Informasi (ASI)}

Aliran Sistem Informasi

(ASI)

menunjukan arus dari laporan dan formulir termasuk tembusan-tembusan seperti pada Tabel 1.

Tabel 1. Aliran Sistem Informasi

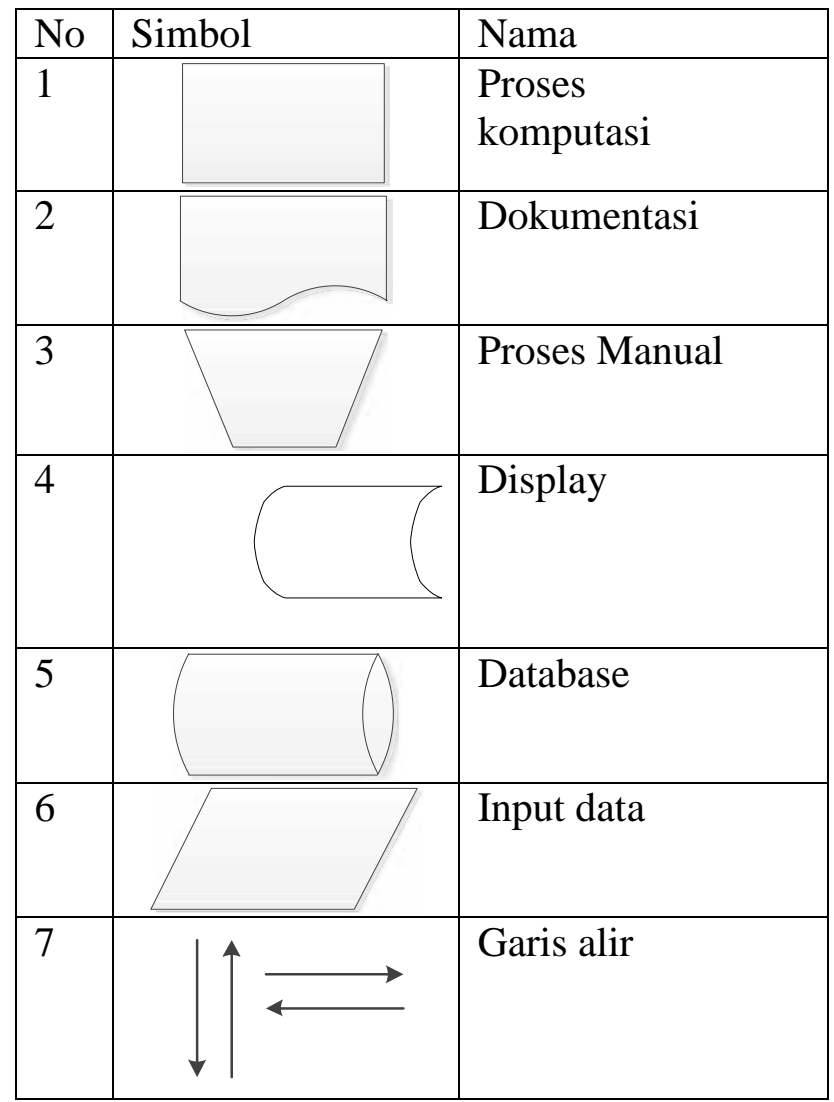




\section{Data Flow Diagram}

Data Flow Diagram atau DFD digunakan sebagai gambaran sistem secara logika yang bersifat khusus dan terperinci. Dimulai dari diagram konteks berisi komponen-komponen sistem, aliran data sistem, asal. Notasi-notasi DFD dijabarkan pada Tabel 2.

Tabel 2. Data Flow Diagram

\begin{tabular}{|c|c|c|}
\hline No. & Simubol & Kegujalais \\
\hline 1. & $\longleftrightarrow$ & 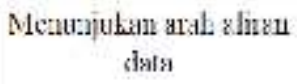 \\
\hline 2. & & Melantaugkan proses \\
\hline 3. & & Nelimbangkan cnt:ty \\
\hline 4. & & $\begin{array}{c}\text { Melambangkin bata } \\
\text { surage }\end{array}$ \\
\hline
\end{tabular}

\section{METODOLOGI PENELITIAN}

Metode penelitian menerapkan pengembangan perangkat lunak Waterfall. Pendekatan waterfall dimulai dari urutan pertama pada level kebutuhan sistem. Urutan kedua merupakan tahap analisis. Berlanjut ke desain. Melakukan coding. Terakhir dengan testing/verification dan maintenance. Waterfal atau air terjun dikenal karna dilakukan pertahap. Setiap tahapan harus dilalui dan harus selesai. Contoh pada tahap desain harus selesai dahulu sebelum tahap tahap requirement dimulai[7].

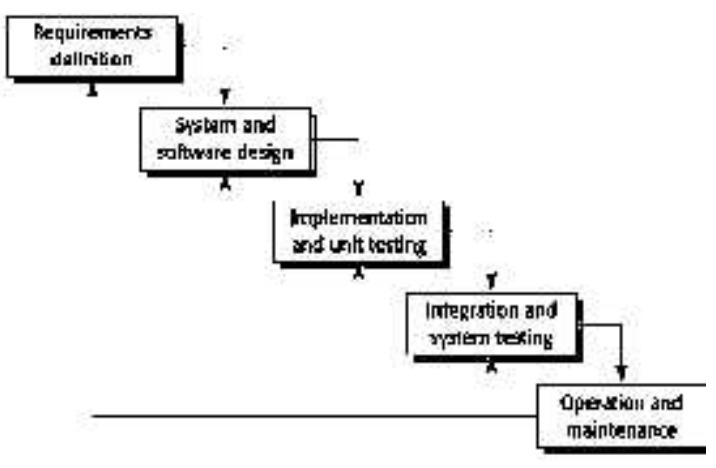

Gambar 1. Metode Waterfall

\section{HASIL DAN PEMBAHASAN}

\section{Flowchart Sistem}

Sistem baru yang diusulkan menjadi alternatif untuk mengatasi permasalahanpermasalahan yang terjadi pada sistem yang sedang berjalan. Terutama sebagai pembanding dan penilai dari sistem yang lama. Sistem baru tidak merubah sistem yang sedang berjalan secara total. Hanya meningkatkan efisiensi dan efektifitas dari kegiatan operasional.

Sistem yang menggunakan alat bantu komputer beserta alat pendukung lainnya ( komputer sebagai alat sistem pengolah data ) mempunyai keistimewaan antara lain :

1. Dapat mengolah data, mengatur serta menyimpan data berjumlah besar menggunakan waktu yang relatif singkat.

2. Kemungkinan terjadi kesalahan kecil.

3. Dapat menginformasikan dengan tepat, akurat dan bahkan cepat. 
4. Dapat meningkatkan efisiensi waktu, tempat, dan tenaga.

5. Keamanan data terjamin.

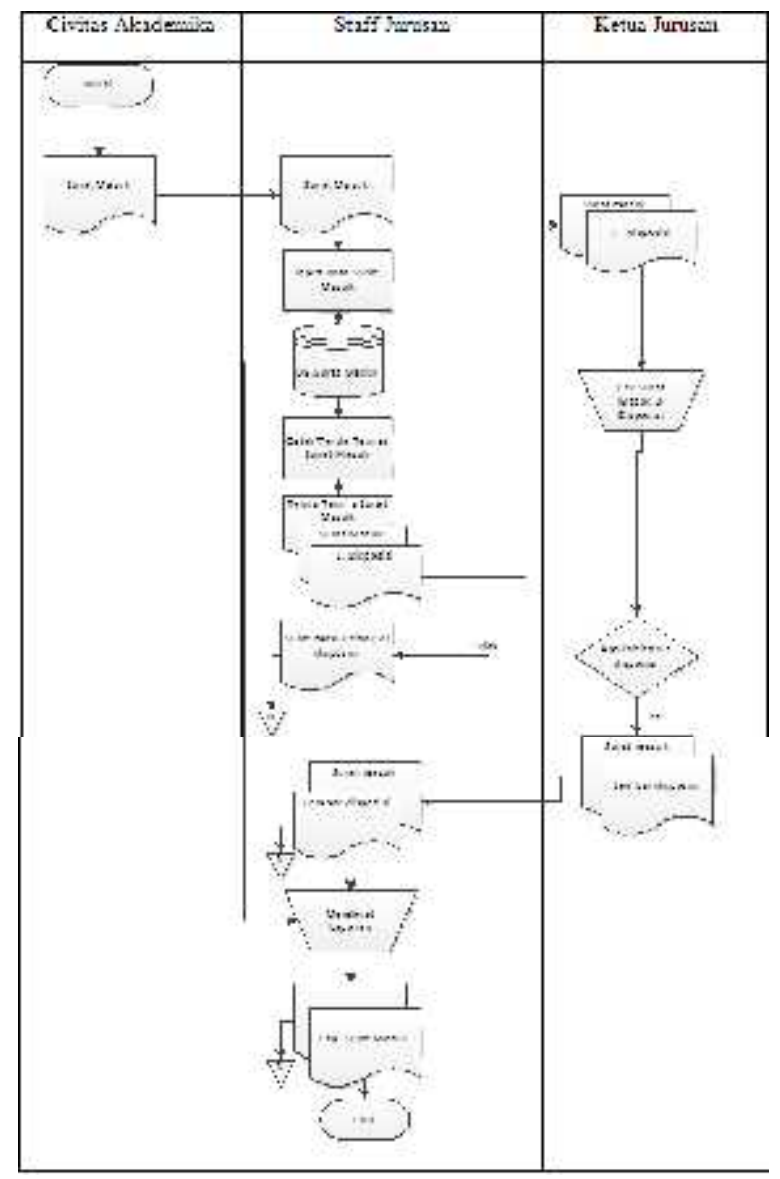

Gambar 3 Flowchart Sistem

\section{Implementasi Sistem}

Implementasi menunjukan hasil akhir dari perancangan dan desain yang telah dilakukan. Pembangunan sistem menerapkan bahasa pemrograman PHP dan framework bootstrap. PHP sebagai bahasa pembangunan website. Sedang framework bootstrap merupakan tempatenya.
Pengarsipan Surat Masuk Dan Surat Keluar

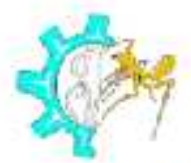

Jurusan SISTEM

INFORMASI

\section{LOGIN}

Gambar 4 Halaman Login

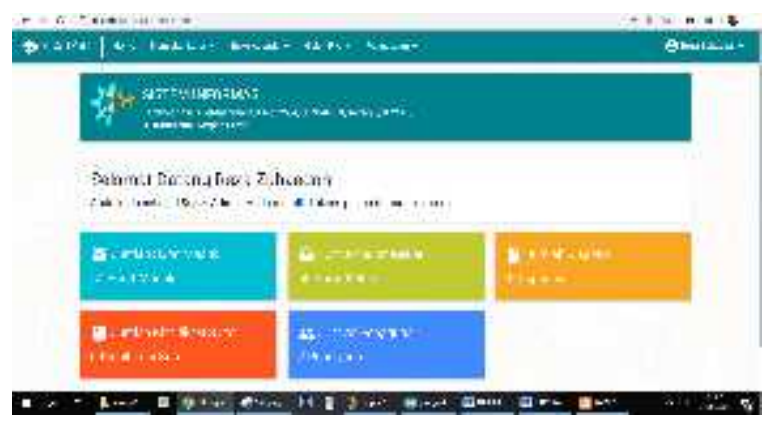

Gambar 5 Dashboard Sistem

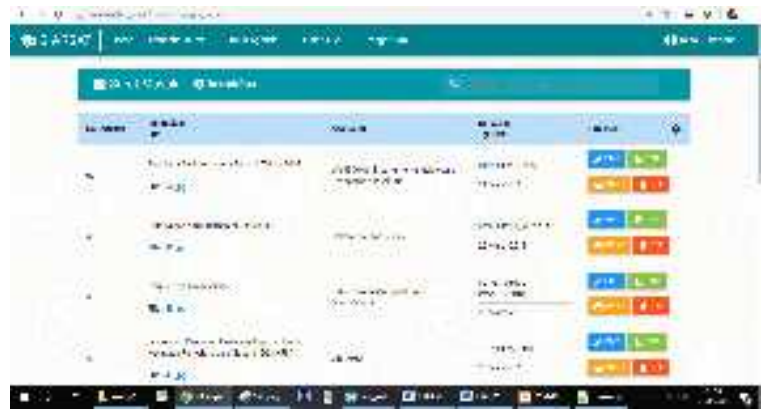

Gambar 6 Olah Data

\section{KESIMPULAN}

Penilitian ini telah berhasil dibuat. Dapat dikatakan bahwa penulis berhasil membangun suatu website yang mampu 
MUSTEK ANIM HA Vol. 8 No. 1, April 2019 e-ISSN : 2354-7707 p-ISSN 2089-6697

mengelola arsip baik dalam bentuk dokumen SOP, surat keputusan, surat keluar, surat masuk hingga memo/disposisi dengan menggunakan framework Bootstrap. Penggunaan website dapat menyelesaikan masalah penggunaan jaringan local sehingga dapat diporoses kapanpun dan dimanapun. Selain itu, kelebihan menggunakan Bootstrap dirasa dalam mengembangan website yang lebih responsif dan mudah. Selain dari pada kebutuhan jurusan Sistem Informasi sendiri, website ini juga bisa menjadi framework dasar bagi jurusan lain di Universitas Musamus.

\section{DAFTAR PUSTAKA}

1. Abdul Kadir, 2003, Pengenalan Sistem Informasi, Yogyakarta : Andi.

2. Rosa \& M.Shalahuddin, 2013, Rekayasa Perangkat Lunak. Bandung : INFORMATIKA.

3. Pedoman Umum Tata Naskah Dinas Elektronik Di Lingkungan Instansi Pemerintahan NOMOR 6 TAHUN 2011.

4. Putra, Apriyansyah. (2015). Sistem Pengarsipan Elektronik Dokumen Mutu Universitas Sriwijaya. Jurnal Generic, Vol. 10, No. 1, Maret 2015, pp. 409 420.

5. Triyono, Samopa, F., \& Burhan, U. (2013). Pembuatan Sistem Informasi Penatausahaan Surat dan Arsip Berbasis Web Studi Kasus Kantor Pelayanan Perbendaharaan Negara
Bengkulu. Jurnal Teknik Polmits Volume 2 No 2 - 2013.

6. Iryanti, E., \& Andriyanto, R. (2016). Sistem Manajemen Dokumen Dengan Metode Framework For The Aplications Of System Technology (FAST), Prosiding Unisbank ke-2 2016

7. Pressman, R.S. Software engineering : $a$ practitioner's approach seventh edition. New York : McGrawHill, 2008. 